\title{
Apical and Laminal Articulations in Hakha Lai
}

\author{
IAN MADDIESON and KENNETH VANBIK \\ University of California, Berkeley
}

\section{Introduction}

Almost every spoken human language has at least one coronal plosive, but only a minority have minimal contrasts between two (or more) coronal plosives made at different places (e.g. dental and alveolar) or with differing tongue gestures (e.g. apical vs laminal). Hakha Lai is one such language: it has four voiceless coronal plosives differing in both place and aspiration. These are exemplified by the words given in Table 1.

Table 1. Words showing four-way voiceless coronal plosive contrast in Hakha Lai

Unaspirated: $\quad /$ taa/ 'possession' /taa/ 'brother (female speaker)'

Aspirated: $\quad / \mathrm{t}^{\mathrm{h}} \mathrm{aa} /$ 'sinew' $\quad \underline{\mathrm{t}}^{\mathrm{h}} \mathrm{aa} /$ 'good'

In this paper we will examine the articulatory and acoustic characteristics of the coronal place contrasts between these voiceless stops in Lai (the transcription used above anticipates our conclusions) and compare their production with that of other coronals in the language. We will also briefly compare the instantiation of the coronal place contrast in Lai with that in certain other languages with generally similar distinctions, and examine the historical origin of the contrast in Lai through its correspondences in related languages.

Hakha Lai is a Tibeto-Burman language of the Kuki-Chin group, spoken in the north-western border region of Burma (Myanmar) and adjoining parts of India (mainly in Mizoram) and Bangladesh. It is the native language of the second author of this paper.

\section{Articulatory Contrast}

We examined the articulatory contrast between these words in the second author's speech using (static) palatography and linguography (for descriptions of these techniques see Ladefoged 1997). The palatograms and linguograms show that the initial segments in the words on the left in Table 1 have a lingual contact which is broad in the sagittal plane, extending over the upper teeth and onto the alveolar ridge behind the teeth. This pattern is illustrated in Figure 1, which shows palatograms of two repetitions of /taa/ 'possession' (top row) and one of $/ \mathrm{t}^{\mathrm{h}} \mathrm{aa} /$ 'sinew' 
(lower left) produced in phrases beginning with the third person marker /a/. The lower right panel of the figure shows a linguogram of the utterance /a taa/ 'his/her possession', confirming that there is a broad contact area on the tongue blade.

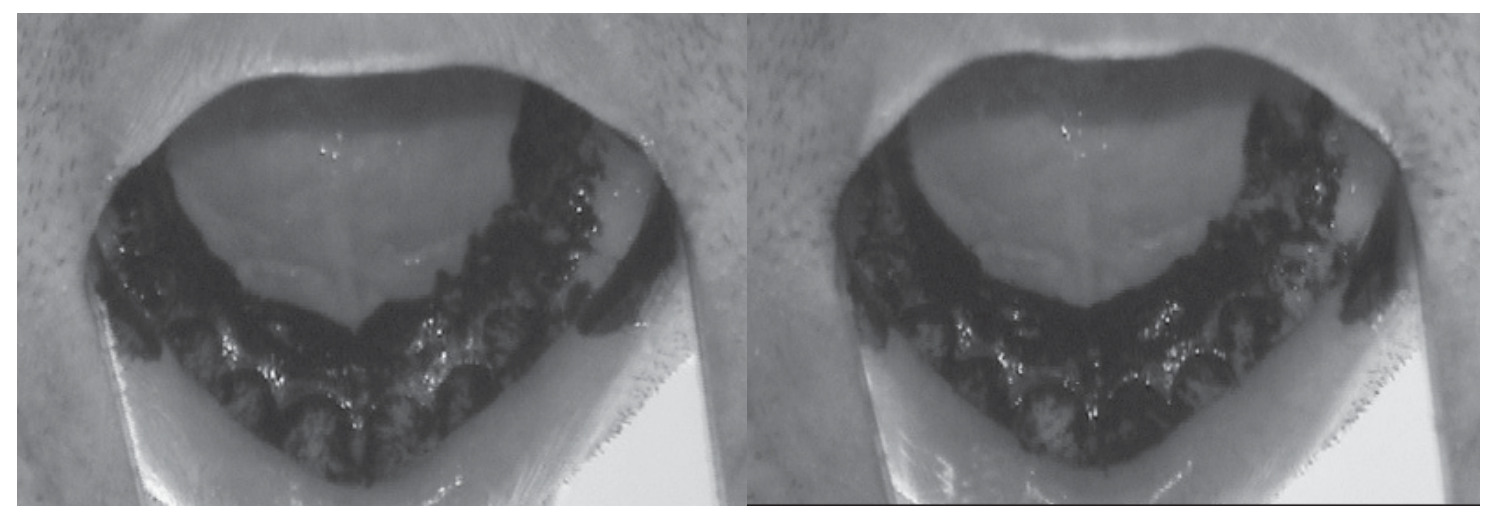

a taa (rep 1)

a traa (rep 2)

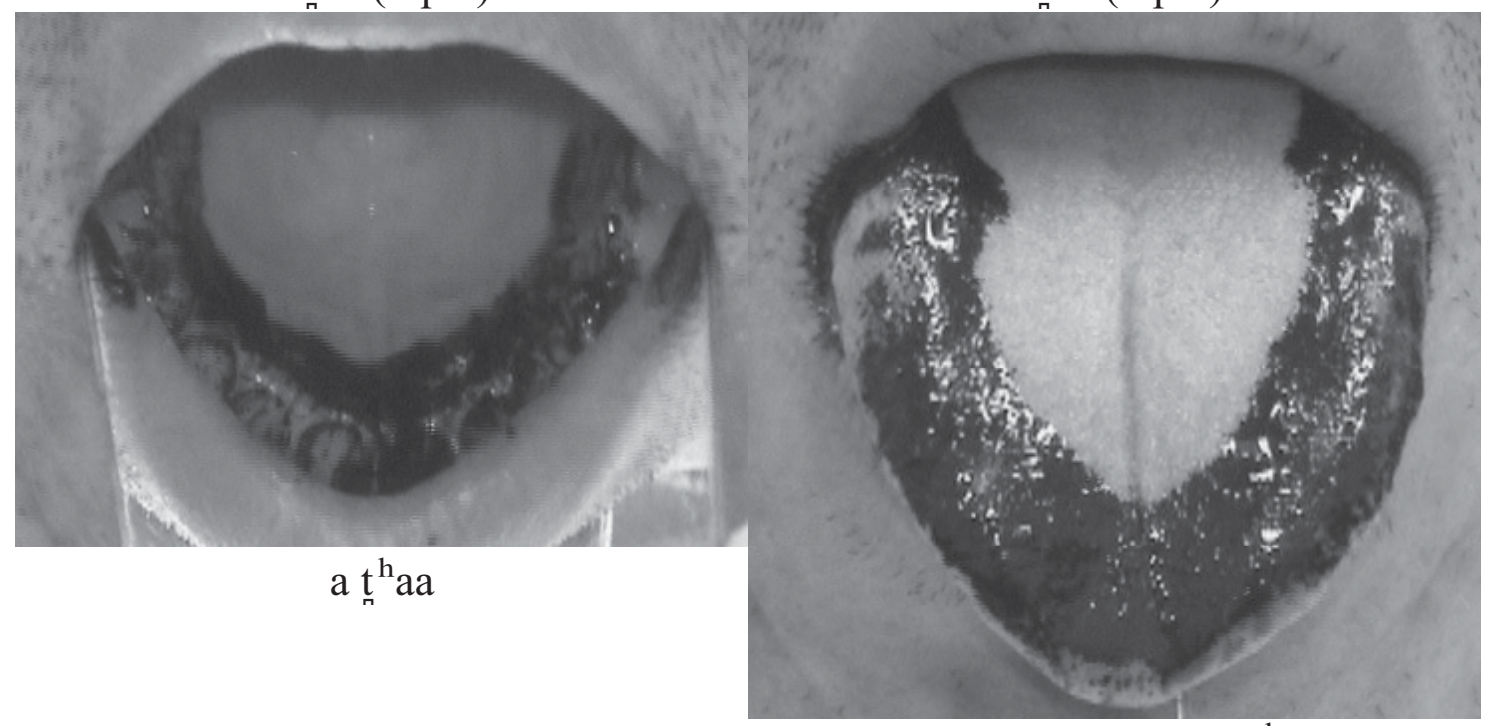

Figure 1. Palatograms of /a taa/ 'his/her possession' (top row) and $/ \mathrm{a} \mathrm{t}^{\mathrm{h}} \mathrm{aa} /$ 'his/her sinew'(bottom left); linguogram of of /a taa/ (bottom right).

On the other hand, the initial segments in the words on the right of Table 1 have a narrower lingual contact in the sagittal plane that is principally behind the teeth. The palatograms for the segment $/ \mathrm{t}$ / show that the contact area primarily lies behind the teeth, on and behind the alveolar ridge. In the first token in Figure 2, the contact pattern is blurred, which suggests that this segment is produced with a dynamic articulation in which the location of contact moves (probably forward) during the closure phase. In the second token the contact area is on the alveolar ridge but extends laterally onto the back of the teeth. This token also shows some evidence of dynamic articulation. The linguogram in the lower right panel of Figure 2 shows that the contact area on the tongue is very narrow at tip. The lower left panel confirms that there is a similar alveolar contact pattern for the aspirated counterpart.

The palatographic and linguographic data indicate that the articulatory 
contrast between the segments can be appropriately characterized as between laminal dental for the segments on the right in Table 1 and apical alveolar to slightly post-alveolar for the segments on the left in Table 1. This conclusion has been anticipated by the choice of diacritics employed in the transcriptions.

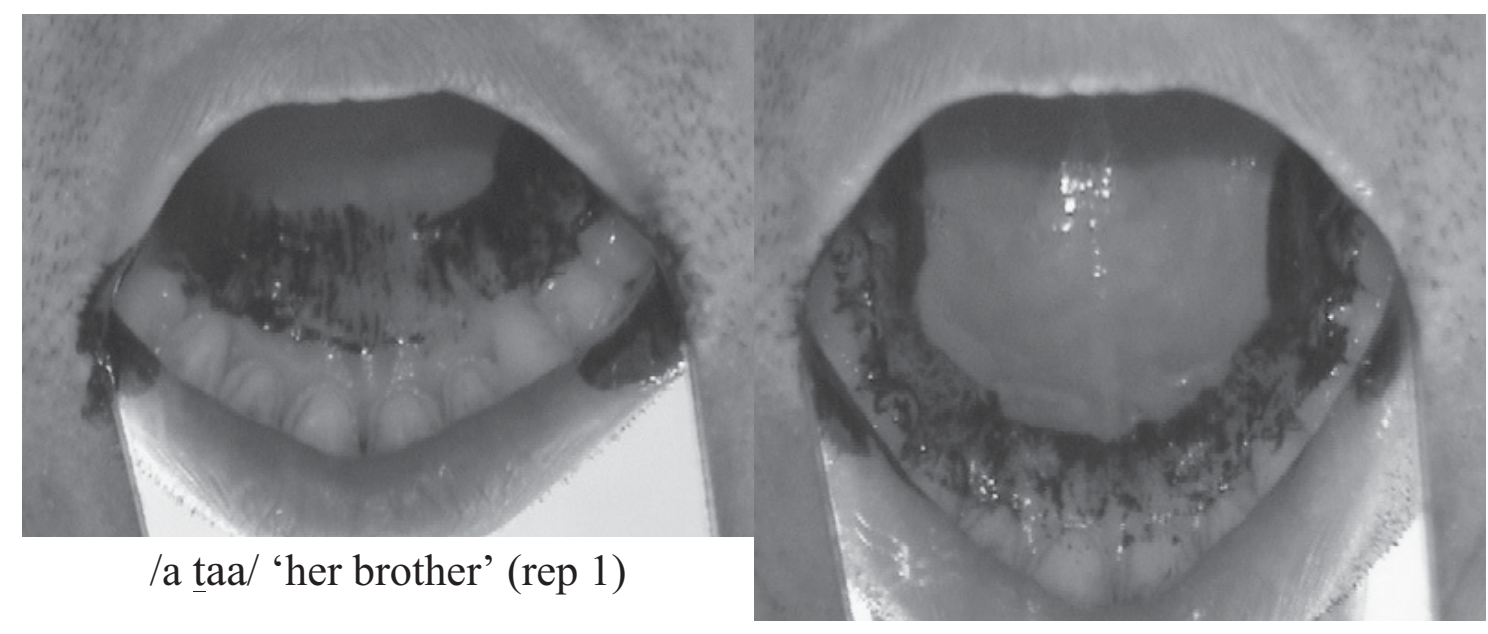

/a taa/ 'her brother' (rep 2)

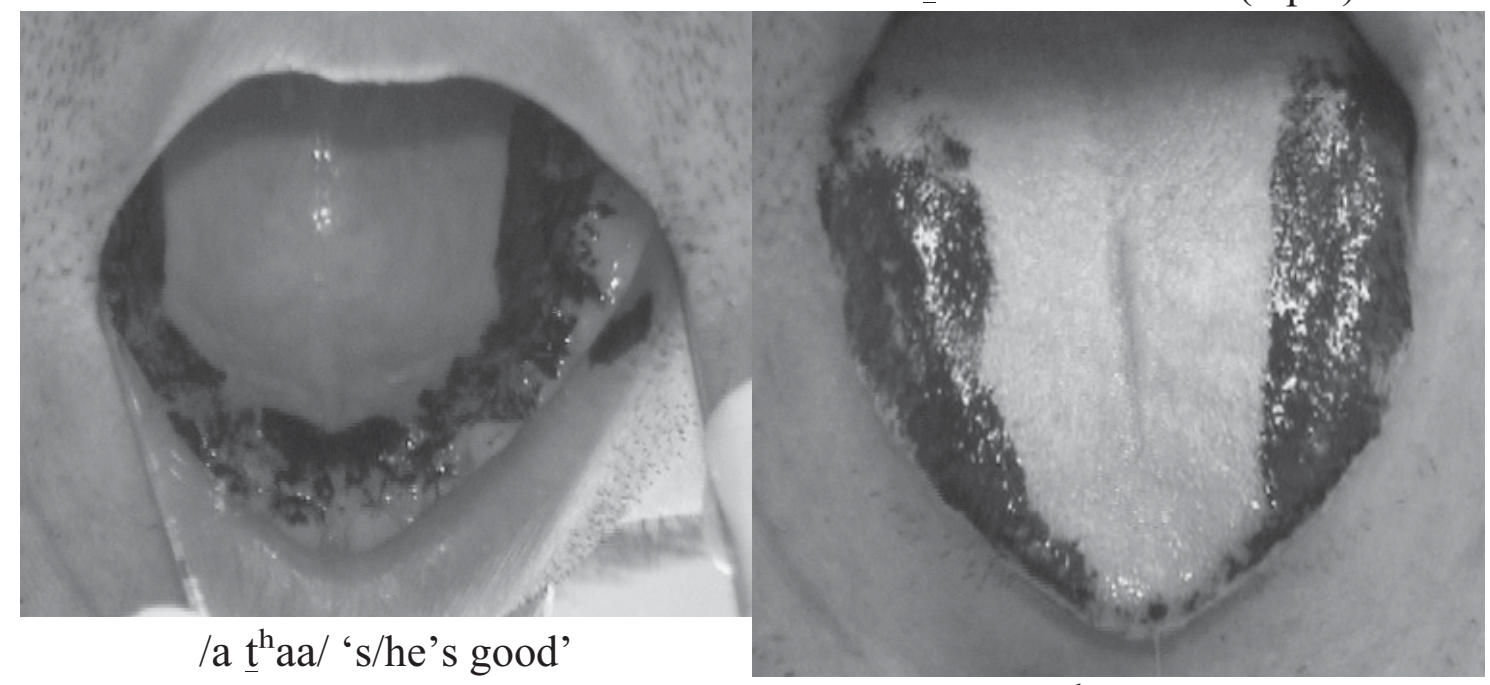

Figure 2. Palatograms of /a taa/ 'her brother' (top row), /a $\underline{t}^{\mathrm{h}} \mathrm{aa} /$ 's/he's good'(lower left), and linguogram of /a taa/ (bottom right).

\section{Acoustic Differences}

We also investigated what acoustic differences correlate with this articulatory distinction. Preliminary inspection of waveforms and spectrograms suggested that both the release burst and the adjoining formant transitions show consonantspecific features. A sample spectrogram contrasting /a taa/ and /a taa/ is shown as Figure 3 below. This unaspirated pair $/$ taa/, / taa/ was chosen for further study. Recordings of two speakers were used, one male (S1), one female (S2), the male being the second author of this paper. The recordings were made digitally at a 44 $\mathrm{kHz}$ sample rate in a sound-attenuated room using a head-mounted close-talking microphone and down-sampled to $22 \mathrm{kHz}$ for analysis.

The values of the second and third formants at the onset of the post- 
consonantal /aa/ vowels were measured in 20 tokens of each of the selected words for S1, and in 16 tokens for S2. In half the tokens the consonants were preceded by the possessive marker $/ \mathrm{a} /$; in the other half the consonants were initial. Formant values were generally obtained from a 24-coefficient LPC analysis using the MacQuirer speech analysis package. A 1024-point FFT analysis and a broadband spectrogram were simultaneously examined to verify the formant estimates, and occasional corrections made based on the FFT spectrum. The mean values are compared in Figure 4. In a two-way analysis of variance with consonant and speaker as independent variables there is a significant difference $(\mathrm{F}$ $(1,68)=140.9, \mathrm{p}<.0001)$ in the second formant onset after $/ \mathrm{t} /$ and $/ \mathrm{t} /$ with the laminal dental having the lower mean value $(1461 \mathrm{~Hz}$ vs. $1621 \mathrm{~Hz}$ for S1, 1884 Hz vs. $2084 \mathrm{~Hz}$ for S2). No significant difference was found for the third formant onset, which is very similar after the two consonants. There is, as expected, a significant difference between the speakers in both formant onsets, with the female speaker having higher onset values.

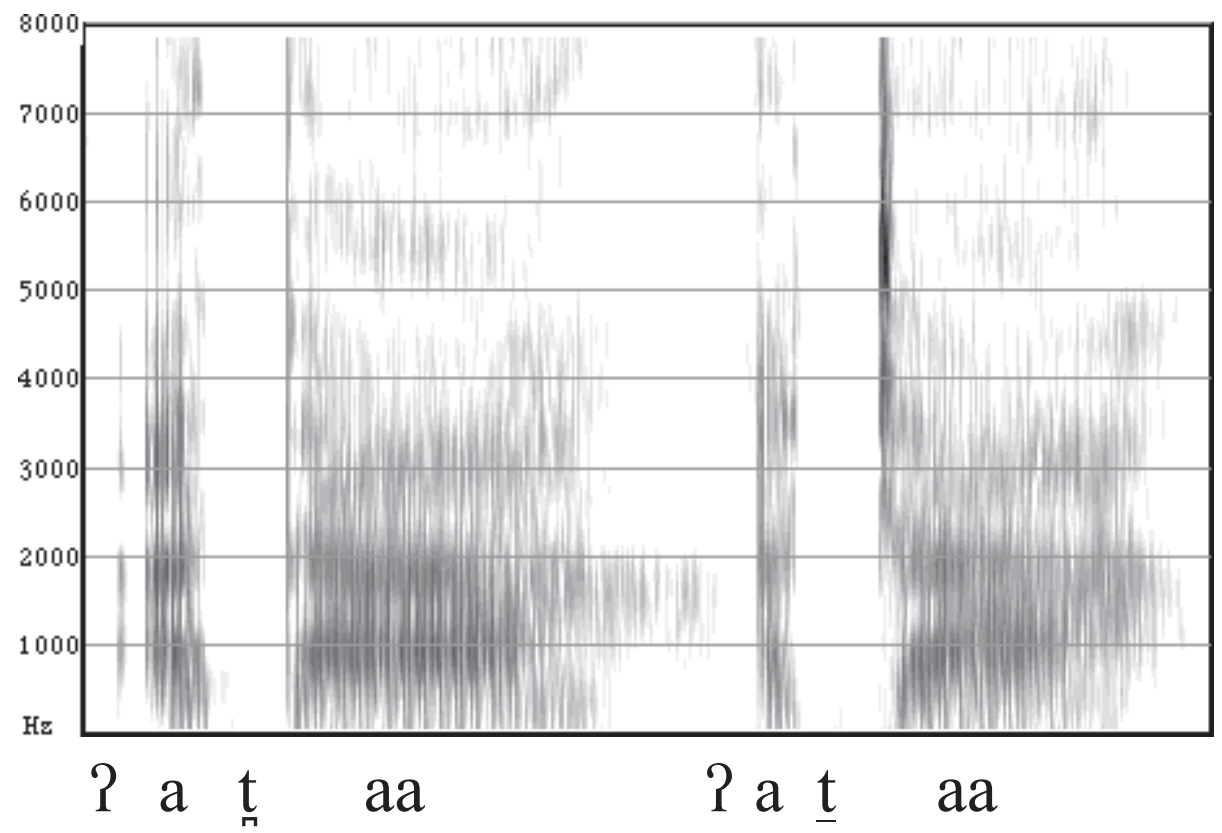

Figure 3. Spectrogram of /a taa/ and /a taa/

Since second formant (F2) onset values following the consonants differed, we compared the second formant offset preceding the consonants in those tokens which had a preceding /a/ (10 tokens of each consonant for S1, 8 for S2). Differences in the tongue position for the two consonants might be anticipated at the moment of closure, or if there is movement during the closure for the alveolar, as is hinted at in the palatograms, disparate values for F2 at the edges of this consonant would be expected. The results were different for the two speakers, as shown in Figure 5. S1 did not show a significant difference between the consonants in preceding F2, but for S2 the second formant is higher before $/ \mathrm{t} /$ than before $/ \mathrm{t} /$, matching the direction of the difference observed for the offset. For both speakers there is a slight rise in the measured F2 value across the closure for the laminal dental $(88 \mathrm{~Hz}$ for $\mathrm{S} 1,57 \mathrm{~Hz}$ for S2). Surprisingly, S1 shows 
effectively identical F2 values on either side of the alveolar consonant, whereas his palatograms suggested that the closure location is moving during the consonant's production. S2 on the other hand shows a notable rise in F2 of 142 $\mathrm{Hz}$ across the consonant closure, which would be consistent with a forward movement of an apical closure during the consonant.

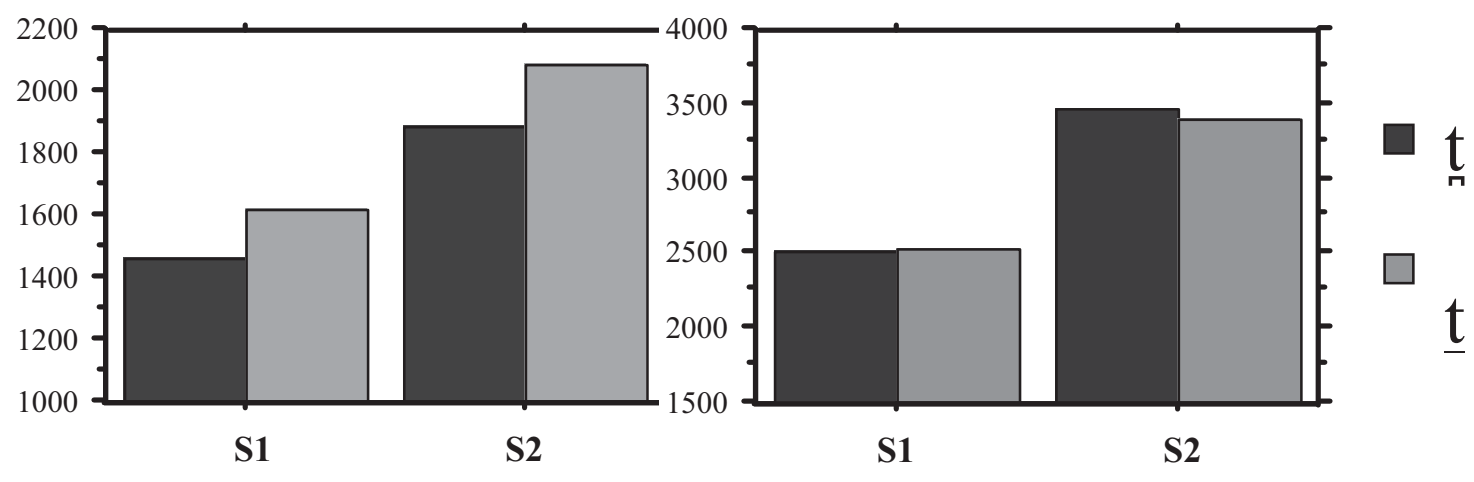

Figure 4. Mean second (left) and third (right) formant onset values after $/ \mathrm{t} / \mathrm{and} / \mathrm{t} /$

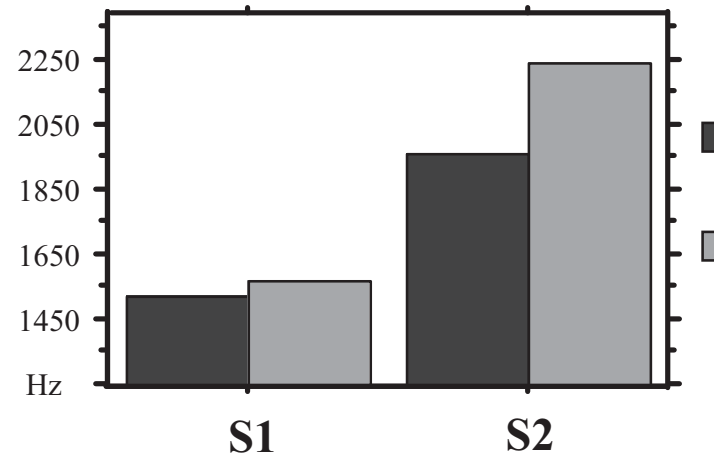

Figure 5. Mean F2 offset

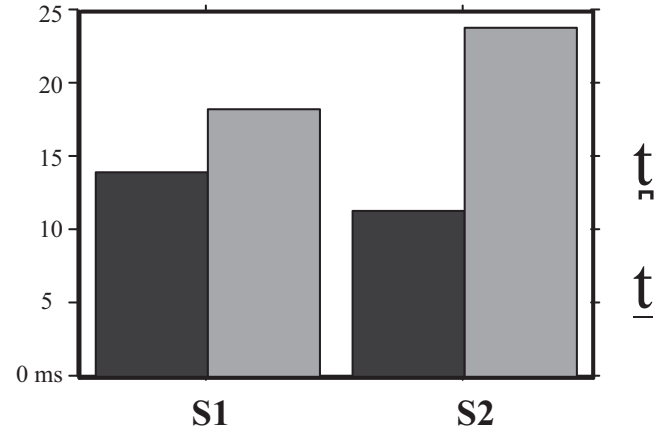

Figure 6. Voice onset time

As noted above, the release bursts after the consonants differ. The interval containing the burst transient and frication noise before the onset of voicing for the following vowel (voice onset time) is significantly longer after $/ \mathrm{t} / \mathrm{than} / \mathrm{t} / \mathrm{F}$ $(1,68)=199.8, p<.0001)$. The results are plotted in Fig. 6 . There is also a significant speaker/consonant interaction, the contrast being greater for S2 than for S1.

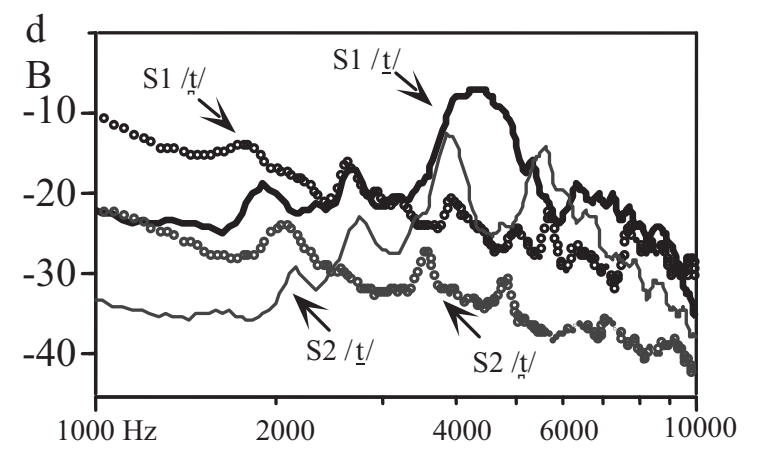

Figure 7. Burst spectra

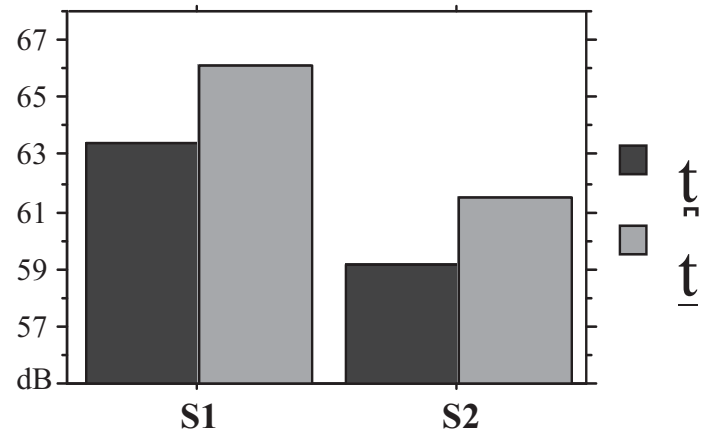

Figure 8. Burst amplitude. 
The energy distribution in the bursts is also distinct. There's a relatively flatfalling spectrum for / $\mathrm{t} /$ but a peaked spectrum for $/ \mathrm{t} /$ with one (for $\mathrm{S} 1$ ) or two (for $\mathrm{S} 2$ ) peaks around 4000-5000 Hz. Mean five-point smoothed FFT spectra calculated over an $11 \mathrm{~ms}$ window from $1000-10,000 \mathrm{~Hz}$ for 20 tokens of each consonant for S1 and 16 for S2 are plotted on a $\log$ frequency scale in Figure 7. Amplitude is shown relative to the peak in the spectrum for each consonant. There is also a significant difference between the consonants in the amplitude of the burst $(F(1,32)=10.7, p=$ .0026) measured in the intervocalic tokens. The alveolar has greater amplitude, as shown in Figure 8.

The closure durations in the intervocalic tokens were also measured and found not to be distinct. The mean durations are plotted in Figure 9, and compared with mean closure duration of /d/ (5 tokens of /d/ for S1, 4 for S2). There is an overall significant difference between speakers, mainly because S2 has considerably longer closures for both voiceless segments, while voiced and voiceless closures are the same for S1.

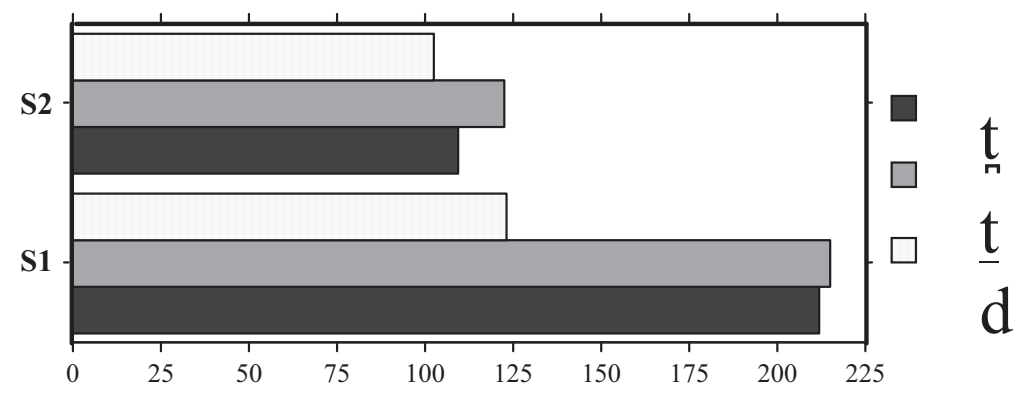

Figure 9. Closure duration in /a taa/, /a t aa/ and /a daa/

\section{Production of Other Coronal Consonants in Lai}

Lai has a large set of coronal consonants but only the voiceless plosives have a laminal dental/apical alveolar contrast. How do the non-place-contrasting coronals align in place? A number of other coronals were investigated using palatography, and a subset of these were also briefly examined acoustically.

The palatography indicates that $/ \mathrm{d} /$ and the sibilant affricates $/ \mathrm{ts}, \mathrm{ts}^{\mathrm{h}} /$ are laminal dental (see Figure 10); the sonorant coronals - nasals, lateral continuants and rhotics-are apical alveolar (Figure 11). The fricatives /s, z/ and lateral affricates are more ambiguous in terms of their assignment to these categories. Their articulation appears to be more alveolar than dental, but the contact is less apical than is seen in the other alveolar segments (Figure 12). Similar differences in place of non-contrasting coronals have been reported for certain other languages: e.g. in the Spanish described by Navarro Tomás (1961), /t, d/ are noted as dental, while /n, 1, s, r/ are classed as alveolar, and Dart (1988) shows French /1/ as most typically apical alveolar while /t, $\mathrm{d} /$ are dental. 


\section{Ian Maddieson and Kenneth VanBik}
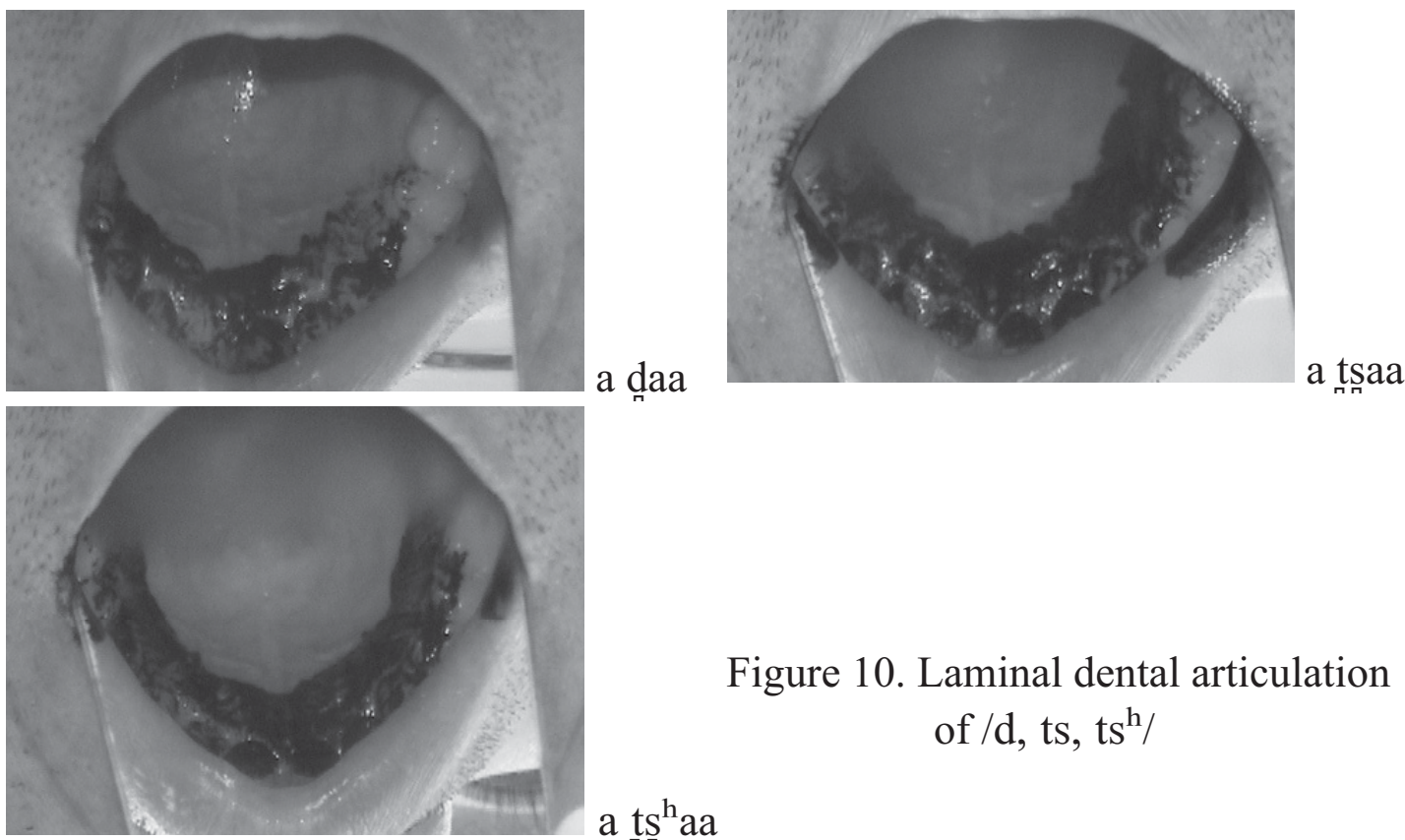

$\mathrm{a} \mathrm{ts}_{n}^{\mathrm{h}} \mathrm{aa}$

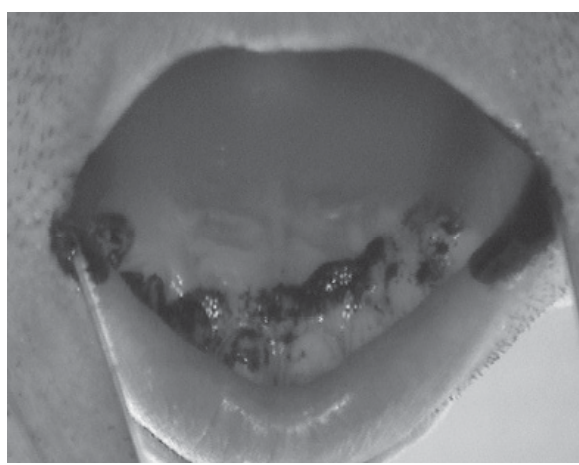

a laa

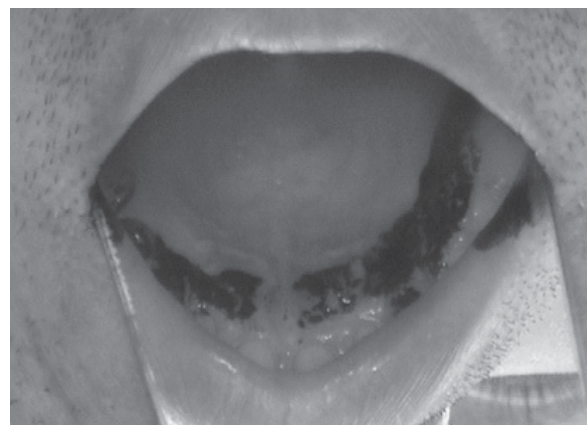

a laa
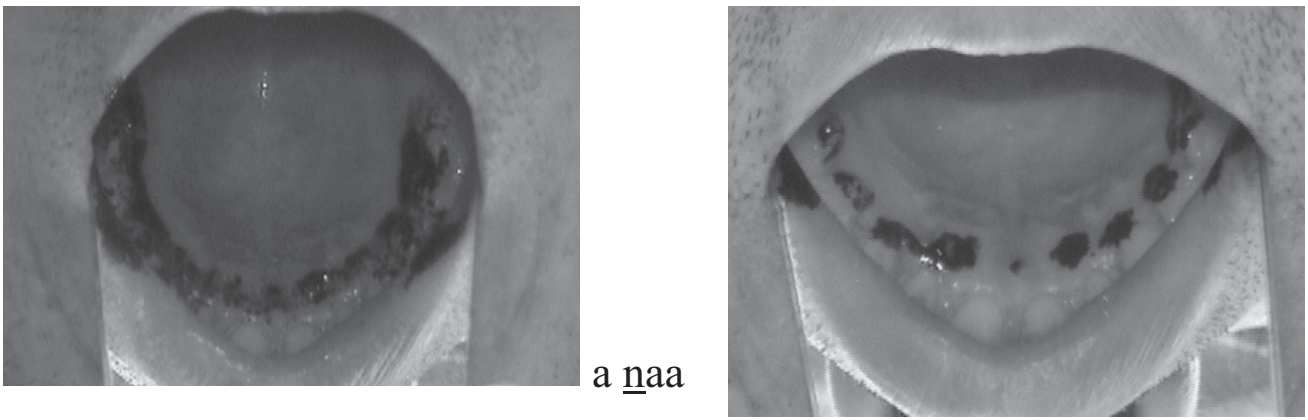

a raa

Figure 11. Apical (post-)alveolar articulation of sonorant coronals

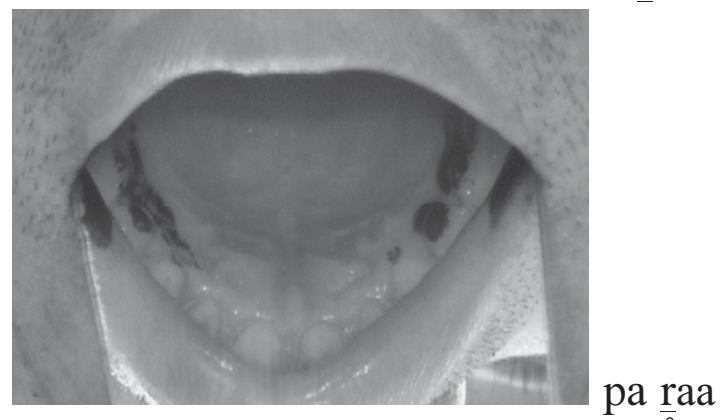



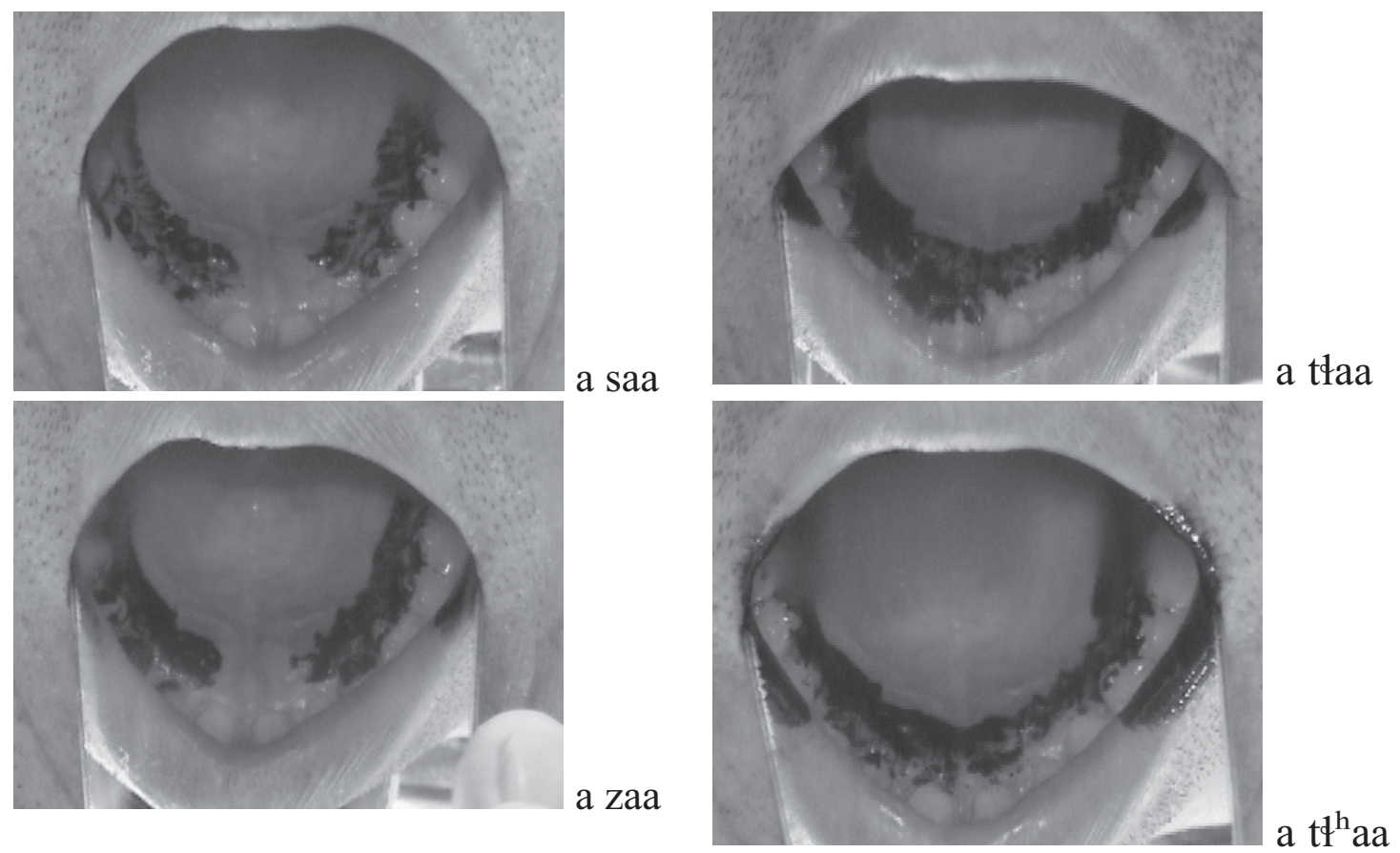

Figure 12. Broad alveolar contact for sibilant fricatives and lateral affricates

The second formant onsets after /d, n, l, r, z/ were also measured in tokens from the two speakers (at least 8 tokens of each type). The level of F2 onset does not correlate with the laminal dental/apical alveolar contrast across the segment types. As shown in Figure 13, [t, d, n] have the highest F2 onsets, [r] the lowest.

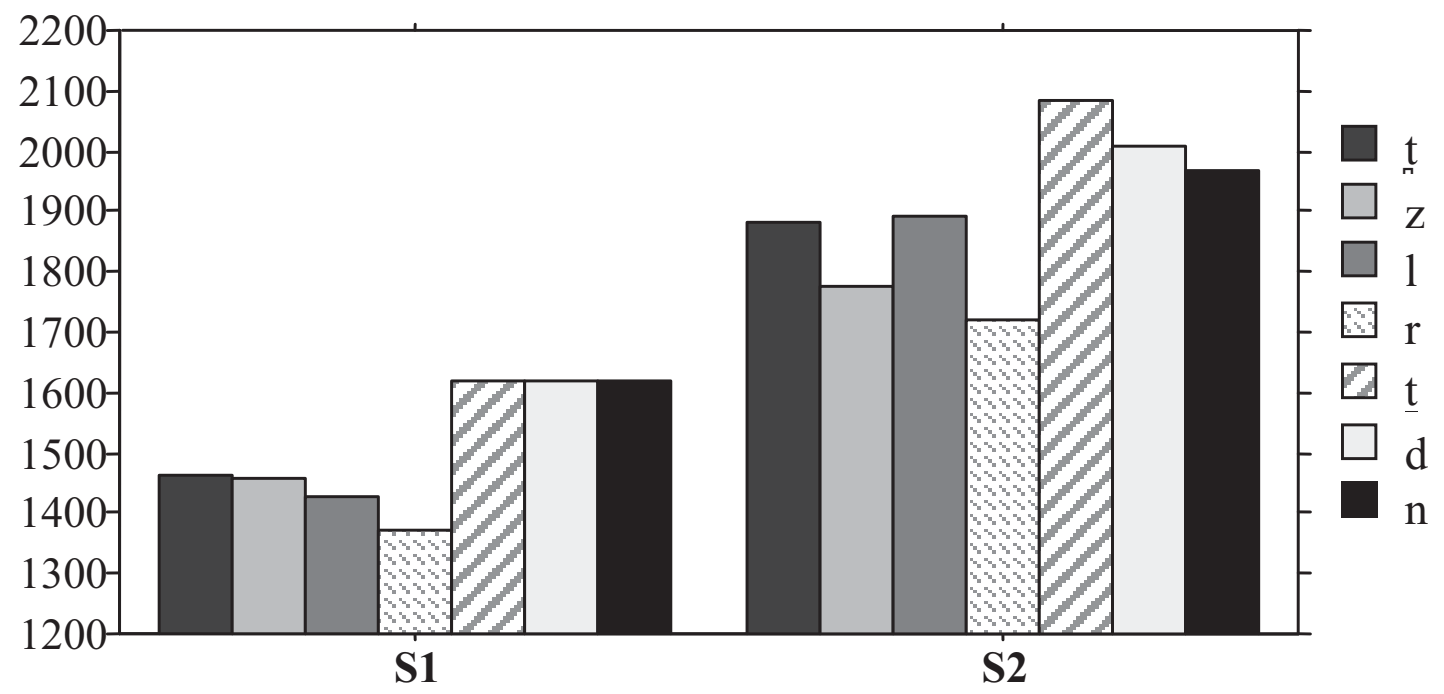

Figure 13. F2 onset after various coronals

\section{Comparison with Dental/Alveolar Stop Contrasts in Other Languages}

Among languages with a broadly similar articulatory place contrast in stops are several languages of the Western US, including O'odham (Pima-Papago) (Dart 1993), many Australian languages, such as Tiwi (Anderson \& Maddieson 1994) 
and Arrernte (Anderson 2000), many languages of India, including Malayalam (Dart 1991) and Toda (Shalev et al 1993), as well as a number of Austronesian languages, e.g. Ndumbea (Gordon \& Maddieson 1999) and African languages such as Dahalo (Maddieson et al 1993). In the five selected comparisons in the boxes that follow similarities with Hakha Lai are shown in italics, differences in bold. There is substantial cross-language variation in implementation. The most consistent pattern seems to be the difference in the burst spectrum, which is flatter for laminal dental stops but more peaked for apical alveolar stops. Burst amplitude is not consistent across the languages, and timing properties are notably variable. We would speculate that some of these differences reflect different origins of the contrast in the various languages, with earlier traits maintained.

O'odham /d/ vs /d/ (Dart 1993)

\begin{tabular}{|c|c|}
\hline Formant transitions & $\begin{array}{l}\text { Higher F2 offset before } / d / \text {; No difference in F2 onset. } \\
\text { Lower } \mathbf{F 3} \text { (and F4) with } / \mathbf{d} /\end{array}$ \\
\hline Burst spectra & $\begin{array}{l}\text { Flat spectrum for } / d / \text {, falling for } / \underline{\mathbf{d}} / \text { (less energy in } \\
\text { higher frequency range) }\end{array}$ \\
\hline Burst duration (VOT) & $\begin{array}{l}\text { No significant difference, but slightly longer for } / \underline{d} / / \\
(15 \mathrm{~ms}) \text { than for } / \underline{\mathrm{d}} /(\mathbf{1 1 . 5} \mathrm{ms})\end{array}$ \\
\hline Burst intensity & No data \\
\hline Closure duration & No data \\
\hline
\end{tabular}

Toda /t / vs / t/ (Shalev et al. 1993)

\begin{tabular}{|ll|}
\hline Formant transitions & No difference in F2 offset before $/ \underline{\mathbf{t}} /$ and $/ \mathbf{t} /$ \\
Burst spectra & More high-frequency energy in burst for $/ \underline{t} /$ than for $/ t /$ \\
Burst duration (VOT) & No significant difference between $/ \mathbf{t} / \mathbf{( 2 2} \mathbf{~ m s )}$ and $/ \underline{t} /$ \\
& $(\mathbf{2 5} \mathbf{~ m s )}$ \\
Burst intensity & Stronger burst for $/ \underline{t} /$ than for $/ t / t$ \\
Closure duration & No data
\end{tabular}

Tiwi /t/ vs / t/ (Anderson \& Maddieson 1994)

\begin{tabular}{|ll|}
\hline Formant transitions & No data \\
Burst spectra & More peaked spectrum for $/ \underline{t} /$ than for $/ t /$ \\
Burst duration & Longer release duration for $/ \underline{t} /$ than for $/ t /$ \\
(VOT) & \\
Burst intensity & More intensity in burst for $/ t /$ than for $/ \mathbf{t} /$ \\
Closure duration & No significant difference between $/ t /$ and $/ \bar{t} /$ \\
\hline
\end{tabular}

E. Arrernte /t / vs / $/$ / (Thaxter \& Maddieson, unpublished)

\begin{tabular}{|c|c|}
\hline Formant transitions & No data \\
\hline Burst spectra & Flat spectrum for $/ t /$, peaked spectrum for $/ \underline{t} \mid$ \\
\hline $\begin{array}{l}\text { Burst duration } \\
\text { (VOT) }\end{array}$ & Slightly longer for $/ \mathrm{t} /(22.8 \mathrm{~ms})$ than for $/ \mathrm{t} /(18.5 \mathrm{~ms})$ \\
\hline Burst intensity & No da \\
\hline Closure duration & $\begin{array}{l}\text { Significantly longer closure for } / \mathrm{t} /(193 \mathrm{~ms}) \text { than for } \\
/ \mathrm{t} /(134 \mathrm{~ms})\end{array}$ \\
\hline
\end{tabular}


Ndumbea /ț / vs / $\underline{t}$ / (Gordon \& Maddieson 1999)

\begin{tabular}{|ll|}
\hline Formant transitions & $\begin{array}{l}\text { Higher F2 onset after } / \underline{t} / \text { than }\left.\right|_{\tau} / \text {; no significant } \\
\text { difference in } F 3\end{array}$ \\
$\begin{array}{l}\text { Burst spectra } \\
\text { Burst duration }\end{array}$ & $\begin{array}{l}\text { Flat spectrum for } / t / \text {, peaked spectrum for } / \underline{t} / \\
\text { (VOT) }\end{array}$ \\
$\begin{array}{l}\text { Burst intensity } \\
\text { Closure duration }\end{array}$ & $\begin{array}{l}\text { No significant difference in burst intensity } \\
\text { Longer closure for } / \underline{\mathbf{t}} / \mathbf{( 1 5 4} \mathbf{~ m s )} \text { than for } / \mathbf{t} / \mathbf{( 1 1 5} \mathbf{~ m s )} \\
\text { (limited data) }\end{array}$ \\
\hline
\end{tabular}

\section{The Origin of the Dental/Alveolar Contrast in Lai}

Hakha Lai dental plosives derive from simple coronal onsets, */t/, */d/ for /t/, */s/ for $/ \mathrm{t} /$. We would therefore presume that the proto-segments were dental in articulation. The alveolar plosives derive from clusters of a labial or velar plosive followed by $* / \mathrm{r} /$, as first noted by Solnit (1979). If */r/ had an alveolar articulation at an earlier stage, the origin of alveolar stops is a fusion of manner from the first element of the cluster and place from the second. We will give a brief sample of data supporting this interpretation of the development of each of the four voiceless coronal plosives of Hakha Lai. Space limitations prevent the inclusion of further material, but details on the reconstruction and history of each of the coronal segments can be found in VanBik (in progress).

On comparative evidence VanBik divides the Kuki-Chin languages into four branches: Northern, Central, Southern, and Maraic. Hakha Lai is a member of the Central branch. The other branches do not have the dental/alveolar contrast, but show distinct correspondences for the two sets. In the boxes below, sample correspondences for the four Hakha Lai stops are given. The proposed ProtoKuki-Chin reconstructions (VanBik, in progress) based on these correspondences as well as Proto Tibeto-Burman reconstructions from Matisoff (2003) where available are also shown.

Cognates of Hakha Lai unaspirated dental plosive.

\begin{tabular}{|lllll|}
\hline & $\begin{array}{l}\text { Northern } \\
\text { (Thado Kuki) }\end{array}$ & $\begin{array}{l}\text { Central } \\
\text { (Hakha Lai) }\end{array}$ & $\begin{array}{l}\text { Southern } \\
\text { (Mindat Cho) }\end{array}$ & $\begin{array}{l}\text { Maraic } \\
\text { (Mara) }\end{array}$ \\
& /t/ & /ț/ & /t, ts/ & /t/ \\
'water' & tûy & t̂̂i & tui & tî \\
'nephew, & & tûu & a tu & tú \\
niece' & & & & \\
\hline
\end{tabular}

\begin{tabular}{|c|c|c|}
\hline & $\underline{\text { Proto-Kuki-Chin }}$ & $\underline{\text { Proto Tibeto-Burman }}$ \\
\hline & $* / \mathrm{t} /$ & $* / \mathrm{t}, \mathrm{d} /$ \\
\hline water' & *tûy & $*_{\mathrm{t}}(\mathrm{w}) \mathrm{i}(\mathrm{y})$ \\
\hline 'nephew, niece' & *tùu & $* \mathrm{du}$ \\
\hline
\end{tabular}


Cognates of Hakha Lai aspirated dental plosive.

\begin{tabular}{|c|c|c|c|c|}
\hline & $\begin{array}{l}\text { Northern } \\
\text { (Thado Kuki) } \\
/ \mathrm{t}^{\mathrm{h}} /\end{array}$ & $\begin{array}{l}\text { Central } \\
\text { (Hakha Lai) } \\
/ \mathrm{t}^{\mathrm{h}} /\end{array}$ & $\begin{array}{l}\text { Southern } \\
\text { (Mindat Cho) } \\
/ \mathrm{s}, \mathrm{t}^{\mathrm{h}} /\end{array}$ & $\begin{array}{l}\text { Maraic } \\
\text { (Mara) } \\
/ \mathrm{t}^{\mathrm{h}} /\end{array}$ \\
\hline 'fruit' & $t^{\text {they }}$ & $\mathrm{t}^{\mathrm{t}}$ ăy / $\mathrm{t}^{\mathrm{h}}$ ay? & $\mathrm{t}^{\mathrm{h}} \mathrm{ei}$ & $t^{\text {théy }}$ \\
\hline 'die’ & $\mathrm{t}^{\mathrm{h}}{ }^{\mathrm{i} \mathrm{i}} / \mathrm{t}^{\mathrm{h}} \mathrm{i} \mathrm{i}$ & $\mathrm{t}^{\mathrm{h}}{ }^{\hat{i}} \mathbf{i} / \mathrm{t}^{\mathrm{h}} \mathrm{h}$ i? & $\mathrm{m}$-sih & $\mathrm{t}^{\mathrm{h}} \hat{\mathbf{1}}$ \\
\hline
\end{tabular}

\begin{tabular}{|c|c|c|}
\hline & $\frac{\text { Proto-Kuki-Chin }}{* / \mathrm{t}^{\mathrm{h}} /(* / \mathrm{s} /)}$ & $\frac{\text { Proto Tibeto-Burman }}{* / \mathrm{s} /}$ \\
\hline fruit' & $* \mathrm{t}^{\mathrm{h}}$ ay & $*_{\text {sat }}$ \\
\hline 'die' & $* \mathrm{t}^{\mathrm{h}} \mathrm{ii} \sim \mathrm{m}$-sii & *səy \\
\hline
\end{tabular}

Cognates of Hakha Lai unaspirated alveolar plosive.

\begin{tabular}{|c|c|c|c|c|}
\hline $\begin{array}{l}\text { 'weep' } \\
\text { 'decrease' } \\
\text { 'uncle' }\end{array}$ & $\begin{array}{l}\text { Northern } \\
\text { (Thado Kuki) } \\
\text { /k, g/ } \\
\text { kàp / kàa } \\
\text { kûm / kùm } \\
\text { găy }\end{array}$ & $\begin{array}{l}\text { Central } \\
\text { (Hakha Lai) } \\
\text { /t/ } \\
\text { tap / ta? } \\
\text { tûm / tŭm } \\
\text { tây }\end{array}$ & $\begin{array}{l}\text { Southern } \\
\text { (Mindat Cho) } \\
\text { /kr, k/ } \\
\text { krap }\end{array}$ & $\begin{array}{l}\text { Maraic } \\
\text { (Mara) } \\
\text { /ts, r/ } \\
\text { tsa } \\
\text { tsáw } \\
\text { pə-rà }\end{array}$ \\
\hline
\end{tabular}

$\begin{array}{llll} & \frac{\text { Proto-Kuki-Chin }}{} & & \text { Proto Tibeto-Burman } \\ \text { 'w/kr/ } & \text { *krap }, \mathrm{gr} / \\ \text { 'decrease' } & \text { *krum } & \text { *krap } \\ \text { 'uncle' } & \text { *kray / ray } & \text { *grum }\end{array}$

Cognates of Hakha Lai aspirated alveolar plosive.

\begin{tabular}{|c|c|c|c|c|}
\hline & $\begin{array}{l}\text { Northern } \\
\text { (Thado Kuki) } \\
/ \mathrm{k}^{\mathrm{h}}, \mathrm{p}^{\mathrm{h}} /\end{array}$ & $\begin{array}{l}\text { Central } \\
\text { (Hakha Lai) } \\
\text { /th/ }\end{array}$ & $\begin{array}{l}\text { Southern } \\
\text { (Mindat Cho) } \\
/ \mathrm{k}^{\mathrm{h}} \text {, ?/ }\end{array}$ & $\begin{array}{l}\text { Maraic } \\
\text { (Mara) } \\
/ \mathrm{t}(\mathrm{s})^{\mathrm{h}}, \mathrm{p}^{\mathrm{h}} /\end{array}$ \\
\hline 'beads' & $\mathrm{k}^{\mathrm{h}} \mathrm{i} \mathrm{i}$ & $\mathrm{t}^{\mathrm{h}} \hat{i} \hat{i}$ & $\mathrm{k}^{\mathrm{h}} \ddot{\mathrm{u} i}$ & $\mathrm{t}^{\mathrm{h}} \mathrm{i}$ \\
\hline 'be good' & $\mathrm{p}^{\mathrm{h}}$ àa $/ \mathrm{p}^{\mathrm{h}}$ at & $\underline{\mathrm{t}}^{\mathrm{h}} \mathrm{a} \mathrm{a} / \underline{\mathrm{t}}^{\mathrm{h}} \mathrm{at}$ & & $\mathrm{p}^{\mathrm{h}} \mathrm{a}$ \\
\hline
\end{tabular}

\begin{tabular}{|c|c|c|}
\hline & $\frac{\text { Proto-Kuki-Chin }}{* k^{h_{r}} n^{h_{r}}}$ & $\begin{array}{l}\text { Proto Tibeto-Burman } \\
* / \mathrm{kr} \text { ? / }\end{array}$ \\
\hline beads' & $* \mathrm{k}^{\mathrm{h}}$ ruy & *krwi(y) \\
\hline be good' & ${ }^{*} \mathrm{p}^{\mathrm{h}}$ raa $\sim \mathrm{p}^{\mathrm{h}}$ rat & \\
\hline
\end{tabular}

6. Summary

Hakha Lai's stop inventory includes a contrast between laminal dental and apical alveolar voiceless plosives. The dental plosives derive from simple coronal 
onsets, */t/, */d/ for $/ \mathrm{t} /, * / \mathrm{s} /$ for $/ \mathrm{t}^{\mathrm{h}} /$. The alveolar plosives derive from clusters of labial or velar plosives followed by $* / \mathrm{r} /$. Primary perceptual cues to the distinction are likely to lie in characteristics of the release bursts and the F2 onset of following vowels. Articulatorily similar contrasts are implemented in different ways in different languages, resulting in language-specific timing, frequency, and amplitude patterns.

\section{Acknowledgements}

The work reported in this paper was supported in part by grant BCS-9817345 from the National Science Foundation to Ian Maddieson and by the Sino-Tibetan Etymological Dictionary and Thesaurus.

\section{References}

Anderson, V. A. 2000. Giving weight to phonetic principles: The case of place of articulation in Western Arrernte. Ph.D. diss., UCLA.

Anderson, V. A., and I. Maddieson. 1994. Acoustic characteristics of Tiwi coronal stops. UCLA Working Papers in Phonetics 87:131-162.

Dart, S. N. 1991. Articulatory and Acoustic Properties of Apical and Laminal Articulations (UCLA Working Papers in Phonetics 79).

Dart, S. N. 1993. Phonetic properties of O'odham stop and fricative contrasts. International Journal of American Linguistics 59:16-37.

Dart, S. N. 1998. Comparing French and English coronal consonant articulation. Journal of Phonetics 26:71-94.

Gordon, M., and I. Maddieson. 1999. The phonetics of Ndumbea. Oceanic Linguistics 38:66-90.

Ladefoged, P. 1997. Instrumental techniques for linguistic phonetic fieldwork. In W. J. Hardcastle and J. Laver, eds., Handbook of Phonetic Sciences, 137-66. Oxford: Blackwell.

Maddieson, I., S. Spajic, B. Sands, and P. Ladefoged. 1993. Phonetic structures of Dahalo. Afrikanistische Arbeitspapiere 36:5-53.

Matisoff, J. A. 2003. Handbook of Proto-Tibeto-Burman. Berkeley, Los Angeles and London: University of California Press.

Navarro Tomas, T. 1961. Manuel de Pronunciación Española (10 ${ }^{\text {th }}$ edition). Madrid: Consejo Superior de Investigaciones Cientificas.

Shalev, M., P. Ladefoged, and P. Bhaskararao. 1993. Phonetics of Toda. UCLA Working Papers in Phonetics 84:89-125.

Solnit, D. B. 1979. Proto-Tibeto-Burman ${ }^{*} \mathrm{r}$ in Tiddim Chin and Lushai. Linguistics of the Tibeto-Burman Area 4.2:111-121

VanBik, K. (in progress). Proto-Kuki-Chin. Ph.D. diss., UC Berkeley.

Department of Linguistics

1203 Dwinelle Hall

ianm@berkeley.edu

University of California, Berkeley

vanbik@berkeley.edu

Berkeley, CA 94720-2650 